\title{
EVOLUTIONARY STUDIES ON \\ MANIOLA JURTINA IN SICILY
}

\author{
R. E. BROCKIE \\ Institute of Zoology, Palermo University *
}

Received 27.viii.71

\section{INTRODUCTION}

THE meadow brown butterfly Maniola jurtina (Lepidoptera, Satyridae) bears a number of black spots on the underside of the hind wings. These spots vary in number from 0 to 5 and, in the absence of any contrary experimental work, it is assumed that this variation is genetically determined. Field collections suggest that a polygenic system works to maintain a balanced ratio of spot frequencies over long periods of time and over wide geographic areas.

Field work in Great Britain, summarised by Ford (1965), and the examination of collections of the insect in British Museums by Dowdeswell and McWhirter (1967) shows that the frequency of spot distribution is stabilised over an area extending from Finland to South France and from Bulgaria to Great Britain. This region has been called the "General European" stabilisation area. Within the general European stabilisation area male insects usually have 2 spots on their hind wings. Others, with 1 or 3 spots are less frequently encountered and fewer still without spots or with 5 spots. Spot distributions among female samples over most of Europe are more variable, most consisting of insects without spots and decreasing numbers having from 1 to 4 spots.

Dowdeswell and McWhirter (1967) argue that the gene systems influencing spotting in $M$. jurtina also operate in $M$. cypricola (Graves) and in $M$. telmessia (Zeller) and that the action of genes with comparable phenotypic effects can be detected in all Satyrine butterflies. They further point out that gene systems which transcend specific and generic limits must be of great antiquity and must have become established far longer than species and genera now existing.

Toward the periphery of its range, however, $M$. jurtina is more variable and samples from Ireland, the Isles of Scilly, the Canary Islands, North Africa, the three peninsulas of Iberia, Italy and Greece, and the west Asian regions show differing stabilisations, each restricted to smaller areas than the large general European area. This geographical variation has been interpreted as showing that uniformity of spotting over most of continental Europe and Great Britain is a response to the average of environmental conditions found there but that smaller, more isolated populations and colonies, may achieve differing adjustments to local conditions.

As a general rule, spot distribution maintains a remarkable stability over long periods in the face of a varied and fluctuating environment but, in Great Britain, shifts in the spot distribution may occur within a season. At Ipswich, Creed et al. (1959) found a greater proportion of many-spotted

* Present address: Zoology Department, Victoria University of Wellington, New Zealand. 
insects in the early emergence of 1957 than were found in the samples which succeeded them in the same season. A similar intra-seasonal change occurred regularly in some Winchester populations (Dowdeswell, 1961, 1962; Beaufoy, Beaufoy, Dowdeswell and McWhirter, 1970). Such intra-seasonal shifts have not been detected in the general European stabilisation area, which has led Dowdeswell and McWhirter (1967) to suggest that the phenomenon may be restricted to populations on the periphery of the continent as a whole.

Among the museum specimens examined by Dowdeswell and McWhirter were a series of collections from Central Italy, Sardinia, Sicily and Malta, covering the years 1896 to 1927 . These show that females from the Central Mediterranean region were highly variable, some resembling French samples, others resembling populations from the Northern Iberian peninsula. Where adequately sampled, the males were all highly spotted with very variable modes of spot distribution.

To throw some more light on the variability of this insect towards the southern periphery of its range, I collected samples of $M$. jurtina (var. fortunata) from three localities in Northern Sicily in 1961 and 1962.

\section{Description of Study areas}

The first Sicilian insects emerged in May, and by June the species was abundant. In the early part of the season butterflies were found in vaguely defined colonies with odd specimens seen between the colonies. As summer progressed and the effects of the prolonged annual drought were felt, Maniola became restricted to the shadier valleys of forests, or to irrigated orchards. None were to be found on open ground after June. In 1962 the autumn rain came earlier than usual and a sudden flush of insects occurred at the end of their season.

\section{Cefalu: 1961,1962}

Most of the insects were taken in two scrub-choked valleys rising from 100 to 200 metres above sea level and overlooking the sea at Contrada Gallizza. Maniola were attracted to flowering scabious and blackberry on open hillsides during the spring but the insects moved into shadier valleys in summer. They showed a special predilection for oak trees, being well camouflaged while resting on the fallen leaves, and they took refuge among the lower branches at night. Although marking experiments were inconclusive it seems likely that the insect's restriction to deep shade in the summer months imposed a barrier on the flow of genes between colonies.

\section{Gibilmanna: 1961, 1962}

Samples were collected in open oak and chestnut forest about $1 \mathrm{~km}$. below the monastery. This colony is at $800 \mathrm{~m}$. above sea level and enjoys a cooler, more humid summer than the colonies at Cefalu and Mondello. Nevertheless, the butterflies moved from the open fields to the forests as summer progressed.

\section{Mondello: 1962}

Insects were collected in a large, thistly, rock-strewn field at the foot of the cliffs behind Mondello Paese. The sudden onset of a harsh summer 
rendered this field unsuitable for Maniola and none were found there after 1st April. Males emerged a week or two earlier than females so, between 9 th and 17th May, 100 males and only 17 females were taken. Once this field dried up it became necessary to collect on an irrigated lemon grove $1 \mathrm{~km}$. away in order to fill out the sample of females. It seems likely that the two sexes are subject to very different selective pressures during the early part of the season at this locality.

\section{RESULts}

Results of collections are summarised in Table 1. To this table are also added details from a collection of Maniola jurtina made in the area around Palermo by Professor M. Marianni between 1930 and 1940 and an analysis of spot distribution among specimens in British museums collected between 1922 and 1927 from "Sicily, mainly Palermo", and examined by Dowdeswell and McWhirter (1967).

\section{Females}

All samples of females showed a bimodal distribution of spot frequency with a major mode at 0 spots and minor modes at either 2 or 3 spots. Insects without spots always exceeded 40 per cent. of any sample and as many as 74 per cent. of a sample from Gibilmanna were spotless.

The mean spot value varied between 0.64 and 1.47 and when the samples are grouped into early- and late-emerging classes it becomes clear that early emergers (before 15th June) have a higher mean spot value than later emergers (after 15th June). The mean spot value for 238 early emergers was 1.04 and for 379 later emergers was $0.93\left(\chi_{(5)}^{2}=24.60 ; \mathrm{P}>0.001\right)$. Between 28th May and 12th June 1961, at Cefalu the mean spot value stood at 1.34. This figure fell to 0.80 between 13 th and 26 th June $\left(\chi_{(5)}^{2}=\right.$ 22.24 ; $\mathrm{P}>0.001)$ and subsequently fell to 0.65 , though no statistical significance can be attached to this change $\left(\chi_{(5)}^{2}=4.47 ; 0.50>\mathrm{P}>0.20\right)$. In May and June of 1962 the mean spot value was again high at 1.47 , falling to 0.69 between August and September $\left(\chi_{(5)}^{2}=41.86 ; \mathrm{P}>0.001\right)$. The female sample taken at Mondello between 9.5.62 and 17.6.62 is homogeneous $\left(\chi_{(5)}^{2}=3.66 ; 0.80 \mathrm{P}>0.50\right)$ with the Cefalu sample collected at the same period and had a mean spot value of $1 \cdot 07$, which is a little higher than average. At Gibilmanna, on the other hand, the mean spot value of females rose from 0.64 to 0.92 between June and August 1961, but this shift was not enough to sway a test of statistical significance. The sample of 90 females collected at Gibilmanna in July 1962 showed a higher (1·16) mean spot value than a sample of 105 females collected in the same place in July and August of the previous year (0.92). This inter-seasonal shift was probably of real significance $\left(\chi_{(5)}^{2}=13.48 ; 0.02>\mathrm{P}>0.02\right)$.

Summarising, it appears that female Maniola jurtina underwent an intraseasonal shift of spot distribution from higher to lower spotted forms at Cefalu in 1961 and 1962, and possibly from a lower to a higher spot number at Gibilmanna in 1961. The pattern of spot distribution found at Cefalu in 1961 and 1962 (bimodal at 0 and 2 spots) was also found at Gibilmanna and Mondello, in Professor M. Marianni's Palermo sample collected in the 1930's and in collections from British museums made between 1922 and 
1927 and mainly from Palermo. Dowdeswell and McWhirter's 1922-27 sample and Professor Marianni's 1930-40 samples are statistically homogeneous $\left(\chi_{(5)}^{2}=0.99 ; 0.98>\mathrm{P}>0.95\right)$ and, when grouped together are homogeneous with the combined 1962-61 samples of 763 females $\left(\chi_{(5)}^{2}=\right.$

TABLE 1

Summary of spot distribution of Maniola jurtina in Sicily

\begin{tabular}{|c|c|c|c|c|c|c|c|c|c|}
\hline \multirow[b]{2}{*}{$\begin{array}{l}\text { Locality } \\
\text { Females }\end{array}$} & \multirow[b]{2}{*}{ Date } & \multicolumn{5}{|c|}{ Spot number } & & $\begin{array}{c}\text { Sample } \\
\text { size a }\end{array}$ & \multirow{2}{*}{$\begin{array}{l}\text { Spot } \\
\text { average }\end{array}$} \\
\hline & & 0 & 1 & 2 & 3 & 4 & 5 & & \\
\hline \multirow[t]{5}{*}{ Cefalu } & 28.5.61-12.6.61 & 49 & 9 & 22 & 26 & 3 & 1 & 110 & $1 \cdot 35$ \\
\hline & $13.6 .61-26.7 .61$ & 65 & 5 & 21 & 3 & 2 & 3 & 99 & 0.80 \\
\hline & $27.7 .61-15.10 .61$ & 36 & 6 & 9 & 1 & 2 & 0 & 54 & 0.65 \\
\hline & $18.5 .62-23.6 .62$ & 6 & 0 & 9 & 1 & 1 & 0 & 17 & 1.47 \\
\hline & $11.8 .62-28.9 .62$ & 17 & 6 & 5 & 0 & 1 & 0 & 29 & $0 \cdot 69$ \\
\hline \multirow[t]{3}{*}{ Gibilmanna } & 13.6 .61 & 40 & 3 & 8 & 3 & 2 & 0 & 56 & 0.64 \\
\hline & 29.7.61-8.8.61 & 59 & 12 & 22 & 7 & 5 & 0 & 105 & 0.92 \\
\hline & $12.7 .62-15.7 .62$ & 44 & 11 & 19 & 9 & 7 & 0 & 90 & $1 \cdot 16$ \\
\hline Mondello & $9.5 .62-17.6 .62$ & 29 & 4 & 11 & 11 & 0 & 0 & 55 & 1.07 \\
\hline Palermo* & $1922-1927$ & 56 & 16 & 33 & 8 & 3 & 0 & 116 & 1.02 \\
\hline Palermo $†$ & $1930-1940$ & 13 & 5 & 7 & 4 & 3 & 0 & 32 & 1.34 \\
\hline \multicolumn{10}{|l|}{ Males } \\
\hline \multirow[t]{5}{*}{ Cefalu } & 28.5.61-12.6.61 & 0 & 0 & 27 & 19 & 20 & 6 & 72 & $3 \cdot 63$ \\
\hline & 13.6.61-26.7.61 & 0 & 4 & 17 & 13 & 19 & 6 & 59 & $3 \cdot 10$ \\
\hline & $27.7 .61-15.10 .61$ & 0 & 0 & 11 & 11 & 19 & 0 & 41 & $3 \cdot 19$ \\
\hline & $17.5 .62-23.6 .62$ & 0 & 0 & 3 & 3 & 3 & 0 & 9 & $3 \cdot 00$ \\
\hline & $11.8 .62-28.9 .62$ & 0 & 0 & 13 & 7 & 9 & 4 & 33 & $3 \cdot 12$ \\
\hline \multirow[t]{3}{*}{ Gibilmanna } & 13.6 .61 & 1 & 1 & 30 & 17 & 27 & 3 & 79 & 2.97 \\
\hline & 28.7.61-8.8.61 & 2 & 3 & 24 & 32 & 38 & 12 & 111 & $3 \cdot 23$ \\
\hline & $12.7 .62-15.7 .62$ & 0 & 3 & 12 & 14 & 19 & 6 & 54 & $3 \cdot 24$ \\
\hline \multirow[t]{2}{*}{ Mondello } & $9.5 .62-17.5 .62$ & 1 & 3 & 37 & 29 & 24 & 6 & 100 & $2 \cdot 90$ \\
\hline & $18.5 .62-16.6 .62$ & 0 & 0 & 19 & 14 & 16 & 1 & 50 & 2.98 \\
\hline Palermo* & $1922-1927$ & 0 & 2 & 12 & 35 & 40 & 24 & 113 & $3 \cdot 64$ \\
\hline Palermo $†$ & $1930-1940$ & 0 & 2 & 8 & 12 & 8 & 3 & 33 & 3.06 \\
\hline
\end{tabular}

$8.48 ; 0.20>P>0.01)$. Thus, despite the extensive intra-seasonal shifts detected in 1961 and 1962 at Cefalu, and the inter-seasonal shift of spot distribution at Gibilmanna between 1961 and 1962, the distinctive bimodal pattern of spot distribution has probably been maintained in the area since 1927 at least.

Males

Between 28.5.61 and 12.6.61, 72 males were taken at Celafu. These showed a bimodal distribution at 2 and 4 spots with a mean spotting value 
of 3.62. Another 59 males collected in the same locality between 13.6.61 and 26.7.61 showed that the mean spotting number had fallen to $3 \cdot 10$ and the proportion of 4-spot individuals rose at the expense of those with 1 spot. Forty-one more males were examined between 27.7.61 and 15.10.61 and this sample showed the proportion of 4-spot insects to have risen substantially, changing the graph of spot frequencies from a bimodal to a unimodal shape.

On 13th June 1961, 79 males were collected at Gibilmanna. These had a mean spotting value of 2.97 and the spots were distributed in a bimodal fashion at 2 and 4 spots. Another sample of 111 specimens, taken 28th July and 8th August 1961, showed the spot average to have risen to 3.23 and, as at Cefalu, the bimodal pattern of spot-distribution to have been transformed into a unimodal pattern at $4 \operatorname{spots}\left(\chi_{(5)}^{2}=11 \cdot 13 ; 0.05>\mathrm{P}>0.02\right)$. Another sample of 54 insects were taken in June of 1962 at Gibilmanna. Like the June-July sample of the previous year, the spot distribution was unimodal at 4 spots and the mean number of spots for the sample was $3 \cdot 24$. These two samples, separated by 11 to 12 months, are statistically homogeneous $\left(\chi_{(5)}^{2}=1.90 ; 0.90>P>0.80\right)$ and show that the spot distribution was stabilised over the two years when collections were made.

Looking backwards over a longer time-scale, it becomes possible to compare Dowdeswell and McWhirter's sample of 113 males, collected mainly in the vicinity of Palermo between 1922 and 1927, and Professor Marianni's 1930-40 sample, collected in the same area. These samples are statistically homogeneous $\left(\chi_{(5)}^{2}=2.22 ; 0.90>\mathrm{P}>0.80\right)$, indicating that the unimodal pattern at 3 or 4 spots apparently persisted unchanged during most of the 1920's and 1930's.

Comparing these early samples with those of 1961 and 1962 is not straightforward because the later collections were made in more restricted areas and because the samples exhibit intra-seasonal shifts in spot distribution. The best that can be done is to group together the whole of the 1961 and 1962 male collections and to compare them with the samples collected three or four decades earlier (table 2).

TABLE 2

The Palermitan spot distributions for 1961-62 compared with 1922-40. Males

$\begin{array}{cccccccccc}\text { Locality } & \text { Dates } & & 0 & 1 & 2 & 3 & 4 & 5 & \text { Totals } \\ \text { Sicily, mainly Palermo } & 1922-1940 & 0 & 4 & 54 & 49 & 65 & 15 & 187 \\ \begin{array}{l}\text { Cefalu, Mondello and } \\ \text { Gibilmanna }\end{array} & 1961-1962 & 4 & 14 & 193 & 159 & 194 & 44 & 608 \\ & \chi_{(5)}^{2}=2 \cdot 07 ; 0.90>\text { P }>0.80 .\end{array}$

This comparison suggests that the bimodal distribution at 2 and 4 spots, which Dowdeswell and McWhirter (1967) call the "Western Mediterranean stabilisation" has persisted in Northern Sicily from the 1920's until 1962 without any radical change. 


\section{Predation by lizards}

It was almost more profitable to collect Maniola during the morning at Cefalu for the number on the wing declined during the day and it was very difficult to find any at all in the late afternoon. This suggested that the butterflies disappeared during the day and were replaced by newly-emerged adults each morning. Eighty-three insects were marked and released in August 1961 but only two recaptured over that period, so it appeared that they were indeed either migrating out of the study area or dying in large numbers.

The green wall-lizard, Lacerta muralis, occurred commonly at all the collection areas and as many as 20 were encountered on one $50-\mathrm{m}$. stroll at Cefalu during the height of the summer. These lizards occasionally snapped at Maniola jurtina and many other species of butterflies which alighted near them. Live butterflies presented to caged lizards were attacked and eaten, but often the lizard seized the insect by the hind wings and the butterfly escaped, leaving part of the wings in the lizard's teeth. Butterflies which had escaped in this way thus bore a distinctive pattern of damage on their hind wings which could be distinguished from other forms of wear and tear. Sometimes the lizards left the imprint of their teeth on the wings.

An analysis of these damaged specimens collected in the field at Cefalu reveals that approximately equal numbers of males and females were attacked and that the lizards did not discriminate between the various spot numbers (see Table 3 ). They could not therefore, be attributed with exerting a selective influence on spot numbers.

TABLE 3

Showing the relationship between the spot number of Maniola and their vulnerability to attack by the Wall Lizard, Lacerta muralis.

\begin{tabular}{|c|c|c|c|c|c|c|}
\hline \multirow[b]{2}{*}{$\begin{array}{l}\text { Spot No. } \\
\text { Males }\end{array}$} & \multicolumn{2}{|c|}{1961} & \multicolumn{2}{|c|}{1962} & \multicolumn{2}{|c|}{ Total for both years } \\
\hline & $\mathbf{E}$ & $\mathrm{D}$ & $\mathbf{E}$ & $\mathrm{D}$ & $\mathbf{E}$ & $\mathrm{D}$ \\
\hline 0 & 3 & 0 & 0 & 0 & 3 & 0 \\
\hline 1 & 2 & 0 & 3 & 1 & 5 & 1 \\
\hline 2 & 41 & 8 & 32 & 7 & 73 & 15 \\
\hline 3 & 48 & 16 & 34 & 9 & 82 & 24 \\
\hline 4 & 57 & 17 & 33 & 4 & 90 & 21 \\
\hline 5 & 10 & 2 & 9 & 0 & 19 & 2 \\
\hline Total & 161 & 43 & 111 & 20 & 272 & 63 \\
\hline
\end{tabular}

\begin{tabular}{|c|c|c|c|c|c|c|}
\hline Females & & & & & & \\
\hline 0 & 95 & 26 & 79 & 14 & 174 & 40 \\
\hline 1 & 21 & 3 & 17 & 3 & 38 & 6 \\
\hline 2 & 35 & 8 & 41 & 6 & 76 & 14 \\
\hline 3 & 7 & 3 & 18 & 2 & 25 & 5 \\
\hline 4 & 6 & 1 & 13 & 0 & 19 & 1 \\
\hline 5 & 0 & 0 & 0 & 0 & 0 & 0 \\
\hline Total & 164 & 41 & 168 & 25 & 332 & 66 \\
\hline
\end{tabular}




\section{Discussion}

Intra-seasonal shifts in spot distribution

The small but consistent intra-seasonal shifts in female spot averages detected in Kent by Creed et al. $(1959,1962)$ and Dowdeswell et al. $(1960)$ and between 1961 and 1968 in certain southern English colonies by Beaufoy et al. (1970) were paralleled in 1961 and 1962 at Cefalu, Sicily. Despite great environmental differences the shift of spotting average among females was in the same direction and on approximately the same scale in both places, suggesting that the same, or very similar, selective agents were at work.

The British workers have reported that male spotting averages also fell in the same southern English colonies, though the fall was smaller than the drop in female spot averages. Shifts detected at Cefalu, Gibilmanna and Mondello, in Sicily, were of roughly the same magnitude as the English shifts, but colonies differed in the direction of this shift.

Regular seasonal shifts in the proportions of genetic morphs are not confined to Maniola jurtina. Dobzhansky (1952) has detected intra-seasonal shifts in the incidence of chromosomal polymorphs among wild populations of Drosophila pseudoobscura at Yosemite Park, California, and these bear a striking resemblance to the intra-seasonal shifts of Maniola. Proportions of Drosophila bearing the "Arrowhead" gene morph showed regular and consistent falls at Yosemite Park between 1946 and 1951 despite wide variations in the climate during those years.

It is generally thought that these rapid evolutionary changes are a response to intense, but opposing, selective pressures (Ford, 1965; Dobzhansky, 1970) yet the causal agents for intra-seasonal shifts remain obscure. The climate appears to have little direct bearing on the phenomenon. Predatory lizards which, in 1961, seemed a possible selective agent, can be ruled out because they appear to attack Maniola adults indiscriminately. Apanteles tetricus, a braconid parasite of Maniola larvae, appears to have some selective effect on spotting number (Dowdeswell, 1961, 1962) but more recent studies by Beaufoy et al. suggest that bacteria infecting the larvae may exert more significant selective pressures.

Dowdeswell and McWhirter (1967) point out that intra-seasonal shifts in spot frequency have not been detected in the large general European stabilisation and they suggest that the phenomenon might be confined to populations on the periphery of the continent. The Sicilian evidence presented here supports their view.

\section{Long-term stabilisation}

Dowdeswell and McWhirter have established that the pattern of spotting frequencies in the General European Stabilisation area have remained constant from the early part of this century to 1966 . The data presented in this paper suggest that the "Western Mediterranean" stabilisation persisted without radical change in the region of Palermo between 1927 and 1962 at least. When compared with other polymorphic species which have been studied over long periods of time, Maniola must be looked upon as having a conservative yet versatile genetic system which has adapted it to wide range of fluctuating environments over at least 60 generations without apparent change.

Pollution by industrial smoke, which has substantially altered the proportion of melanic morphs of between 70 and 100 species of moths in 
Britain (Kettlewell, 1961), and pollution by DDT and other insecticides, which may possibly have altered the proportions of chromosomal polymorphs of Drosophila pseudoobscura along the western seaboard of the United States between 1940 and 1965 (Dobzhansky et al., 1966), appear to have left Maniola morph ratios untouched over most of Europe and in Sicily.

\section{Summary}

1. Collections of Maniola jurtina made at three localities in Northern Sicily in 1961 and 1962 show that the frequency distribution of spots differed from that found throughout most of Continental Europe.

2. Females showed a bimodal spot distribution at 0 and 2 or at 0 and 3 spots in the three colonies sampled. An intra-seasonal shift from higher to lower average spotting was detected at Cefalu in 1961 and again in 1962.

3. Male samples underwent intra-seasonal variation from a bimodal distribution at 2 and 4 spots during early emergence at Gefalu and Gibilmanna to a unimodal distribution of 4 spots during later emergence.

4. The intra-seasonal shift among females is in the same direction and on approximately the same scale as similar shifts in colonies at Winchester and Kent, England, suggesting that similar selective agents were at work in both localities.

5. Intra-seasonal shifts in the pattern and spot average of Sicilian males varied from colony to colony.

6. These observations bear out Dowdeswell and McWhirter's suggestion that intra-seasonal shifts in spot frequencies are characteristic of those populations at the periphery of the continent.

7. Comparisons between the 1961-62 samples and collections made between 1922 and 1940 around Palermo suggest that the patterns of spot frequencies have remained unchanged over at least 35 years.

8. The wall lizard, Lacerta muralis, preys on adult Maniola jurtina but it does not appear to select one sex in preference to the other, nor does it discriminate between one spot number and another.

Acknowledgements. - I am much indebted to Professors G. Riverberi and G. Minganti of the Zoological Institute, Palermo University, for making facilities available; to Professor M. Marianni, also of Palermo University, for allowing me to examine his collection. I am also grateful to Dr E. B. Ford, F.R.S., for encouraging and helpful discussion, and Dr E. R. Creed, who kindly checked an earlier draft of this paper and suggested a number of improvements.

\section{REFERENGES}

BEAUFOY, E. M., BEAUFOY, S., DOWDESWELL, W. H., AND MCWHIRTER, K. G. 1970. Evolutionary studies on Maniola jurtina (Lepidoptera Satyridae): The Southern English stabilisation 1961-68. Heredity, 25, 105-112.

GREED, E. R., DOWDESWELL, W. H., FORD, E. B., AND MCWHIRTER, K. G. 1959. Evolutionary studies on Maniola jurtina: the English mainland 1956-57. Heredity, 13, 363-91.

GREED, E. R., DOWDESWELL, W. H., FORD, E. B., AND MCWHIRTER, K. G. 1962. Evolutionary studies on Maniola jurtina: the English mainland 1958-60. Heredity, 17, 237-265.

DoBzhansky, TH. 1952. Genetics of natural populations XX. Changes induced by drought in Drosophila pseudoobscura and D. persimilis. Evolution, 5, 234-43.

dobzhansky, тh. 1970. Genetics of the Evolutionary Process. Columbia University Press. 
DOBZHANSKY, TH., ANDERSON, w. w., AND PAVlOvSKy, O. 1966. Genetics of natural populations. XXXVIII. Continuity and change in populations of Drosophila pseudoobscura in western United States. Evolution, 20, 418-27.

DOWDESWELL, W. H. 1961. Experimental studies on natural selection in the butterfly Maniola jurtina. Heredity, 16, 39-42.

DOWDESWELL, W. H. 1962. A further study of the butterfly Maniola jurtina in relation to natural selection by Apanteles tetricus. Heredity, 17, 513-23.

DOWDESWELL, W. H., FORD, E. B., AND MCWHIRTER, K. G. 1960. Further studies on the evolution of Maniola jurtina in the Isles of Scilly. Heredity, 14, 333-364.

DOWDESWELL, W. H., AND MCWHIRTER, K. G. 1967. Stability of spot-distribution in Maniola jurtina throughout its range. Heredity, 22, 187-210.

FORD, E. B. 1965. Ecological Genetics (2nd edn). Methuen.

KETtLeWELL, H. B. D. 1961. The phenomenon of industrial melanism in the Lepidoptera. Annual Review of Entomology, 6, 245-62. 